\title{
Contact Allergic Cheilitis Secondary to Latex Gloves: a Case Report
}

\author{
Shishir Ram Shetty ${ }^{1}$, Anusha Rangare ${ }^{1}$, Subhas Babu ${ }^{1}$, Prasanna Rao ${ }^{2}$ \\ ${ }^{1}$ Department of Oral and Maxillofacial Radiology, AB Shetty Memorial Institute of Dental Sciences, Nitte University, \\ Deralakatte, Mangalore, Karnataka, India. \\ ${ }^{2}$ Department of Oral and Maxillofacial Radiology, Yenepoya Dental College, Yenepoya University, Deralakatte, Mangalore, \\ Karnataka, India.
}

\section{Corresponding Author:}

Shishir Ram Shetty

Department of Oral Medicine and Radiology

AB Shetty Memorial Institute of Dental Sciences

Nitte University, Deralakatte, Mangalore, Karnataka

India

Phone: +919986221047

E-mail: drshishirshettyomr@yahoo.com

\begin{abstract}
Background: The purpose of this report is to present a rare case of allergic chelitis secondary to latex in an elderly diabetic patient. There are very few reported cases of allergic cheilitis in literature. Most of the reported cases of allergic chelitis were secondary to cosmetics, tooth pastes or impression materials. Few cases of rubber dam induced allergic cheilitis and stomatitis reported.

Methods: Since the patient was diabetic on insulin therapy and belonged to the elderly age group, utmost caution was observed while performing diagnostic tests and treatment procedures. The use test was performed to detect the allergen (latex) because of short contact time to the skin surface.

Results: The patient was followed-up for a period of eight months, complete healing of the lesions was witnessed. The patient has not reported of any lesions later.

Conclusions: Appropriate diagnostic test and interdisciplinary approach in consultation with medical specialists would be ideal for the management of allergic cheilitis especially in diabetic elderly patients.
\end{abstract}

Keywords: cheilitis; allergic contact dermatitis; latex hypersensitivity; elderly; dental care for aged; diabetic complications.

Accepted for publication: 23 January 2011

To cite this article:

Shetty SR, Rangare A, Babu S, Rao P. Contact Allergic Cheilitis Secondary to Latex Gloves: a Case Report.

J Oral Maxillofac Res 2011 (Jan-Mar);2(1):e5

URL: http://www.ejomr.org/JOMR/archives/2011/1/e5/v2n1e5ht.pdf

doi: $10.5037 /$ jomr.2011.2105 


\section{INTRODUCTION}

Latex is derived from the fluid contained in tissue beneath the bark of the rubber tree, Hevea Brasiliensis. William Halstead introduced latex surgical gloves in 1890. A century passed by when Nutter reported the first case of latex allergy in 1979 [1]. Since then, latex allergy although rare has become an emerging and serious phenomenon that has implications not just for health care providers, but also for society. Natural rubber latex is found in over 40,000 products that are used in healthcare settings as well as in the home [2]. Latex hypersensitivity in dental patients and practitioners has significantly increased since the introduction of universal precautions for infection control over 20 years ago and will undoubtedly rise in future $[\underline{3}, 4]$. The most frequent risk of population for the latex allergy includes children with spina bifida, people with a family or personal history of allergy (atopy), those exposed to latex through occupational or surgical means, latex-fruit syndrome, healthcare workers, spinal cord injuries, congenital urogenital abnormalities and patients undergoing repeated surgical procedures or internal examinations $[\underline{3}, \underline{5}]$. Latex fruit syndrome is a condition wherein some latex allergens cross react with plant derived food allergens $[\underline{6}, \underline{7}]$.

The prevalence of latex allergy in general population though not accurately documented is believed to be very low. The American Dental Association conducted a study as a part of their annual health screening wherein they found that $6.2 \%$ of the participants comprising of dentists, dental hygienist, and dental assistants, tested positive for type I hypersensitivity to latex proteins [1] The latex allergy reactions could vary from localized stomatitis to life threatening airway compromise [8]. Allergic cheilitis occurs most commonly due to cosmetic products, especially lipsticks and fragrance mixes [9-15] or toothpaste $[\underline{16}, \underline{17}]$. Rare cases of allergic cheilitis secondary to use of rubber dam (latex and non latex types) $[18,19]$ and dental materials $[20]$ have also been reported.

\section{CASE DESCRIPTION AND RESULTS}

A 61 year old female patient reported to the Department of Oral and Maxillofacial Radiology, AB Shetty Memorial Institute of Dental Sciences, Nitte University, Deralakatte, Mangalore, Karnataka, India with complaint of ulceration on the lower lip since four days. The patient visited a local dentist six days ago for dental prosthesis. The dentist performed impression procedures and recalled her after two days. Two days after the impression procedure, the patient noticed multiple erosions and ulcerations on both upper and lower lips. The erosions were associated with bleeding and severe burning sensation. The patient also stated that there was severe itching and mild redness on the skin which reduced within few hours. There was no history of such oral eruptions or allergic reactions to the drugs, food or cosmetic products in the past. Patient's medical history revealed that she was diabetic since 20 years and was on regular medication (insulin injections - 12 units/day subcutaneously). Patient resided in a rural area but did not practice any deleterious habits. No other co-morbid medical factors were reported.

Intraoral examination revealed ulcerated and eroded areas on the lower lip (Figure 1A). The lesion was extending from the right angle of the mouth to the left side, superiorly from the vermilion border of the lip to $2 \mathrm{~mm}$ from the cutaneous margin of the lip (Figure 1B). The surface of the lesion was a mixture of ulcerated eroded and crusted areas, the lip was swollen throughout. The lower anterior teeth had gingival recession and deposits of the calculus (Figure 1C),

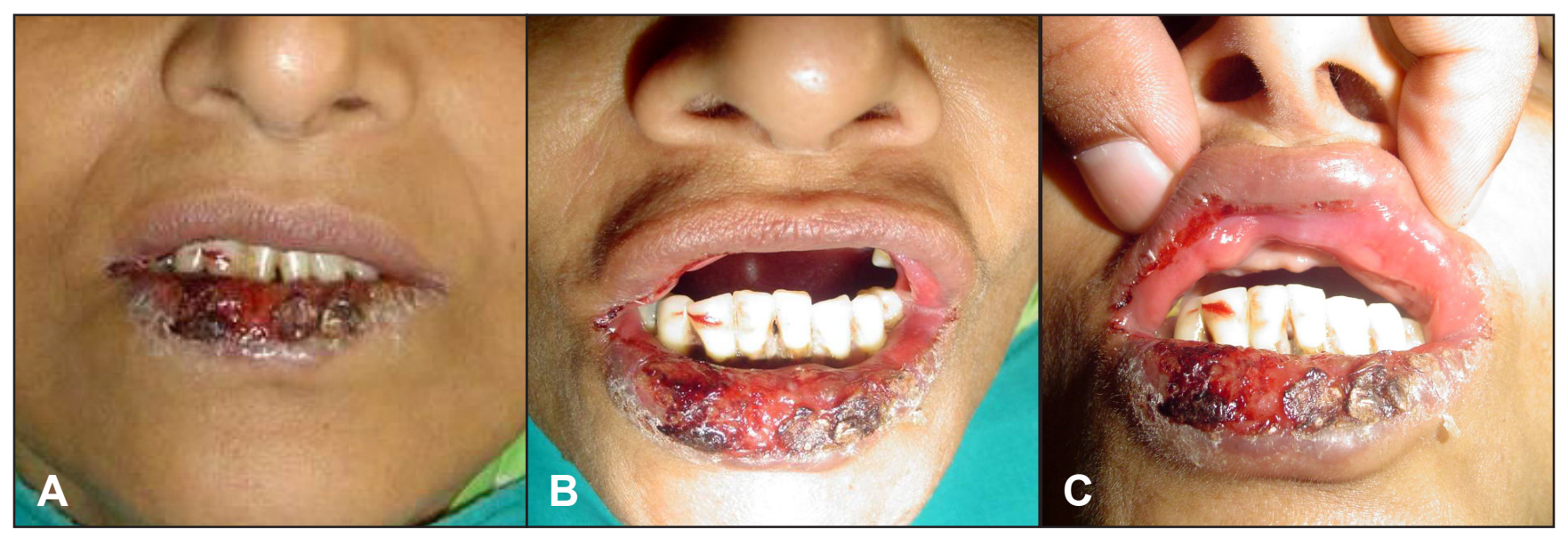

Figure 1. $\mathrm{A}=$ Erosions and crusted areas on the lower lip. $\mathrm{B}=$ Erosions on the upper lip. $\mathrm{C}=$ Supragingival calculus and stains on the lower anterior teeth. 
which was in close approximation with the lesion. Other areas of the oral mucosa were normal. A diagnosis of allergic chelitis was made and the dental surgeon's gloves or the impression material was thought to be the possible allergen. The impression material would have caused intraoral lesions rather than lip lesions, so the gloves were thought to be the cause for the allergic reaction. Erythema multiforme, exfoliative chelitis and actinic chelitis were the other possible differential diagnosis which could be ruled out based on the fact that the lesion was acute in nature and absence of any history of the skin reactions to sunlight. Viral eruptions could be ruled out due to the lack of other symptoms. On further enquiry the local dentist revealed that latex gloves containing natural latex powdered with bioabsorbable cornstarch and fast setting alginate material were used during impression procedure.

The blood sugar levels, both fasting and post prandial were within the normal range. Immunological blood tests could not be performed because of the lack of facility in our institution. After consulting a medical specialist an allergen test (use test) was performed using cut glove finger tip (same brand of gloves was used), dipped in saline applied on the patient's forearm for 15 minutes (Figure 2A). Erythematous areas were noticed at the site of application (Figure. 2B). The patient was admitted to the hospital and administered oral antihistaminic (pheniramine maleate $25 \mathrm{mg}$ thrice daily), topical corticosteroid (triamcinolone acetonide $1 \%$ thrice daily) over the lesion and amoxicillin $500 \mathrm{mg}$ orally thrice daily for 5 days to prevent any secondary infection. Thorough scaling was performed after six days using polythene gloves to prevent secondary infection. The patient was reviewed and discharged after 7 days (Figure 3A). Considerable healing of the lip lesions was noticed at the time of her discharge. The patient was reviewed after 8 months and complete healing of the lesion was noted (Figure 3B).

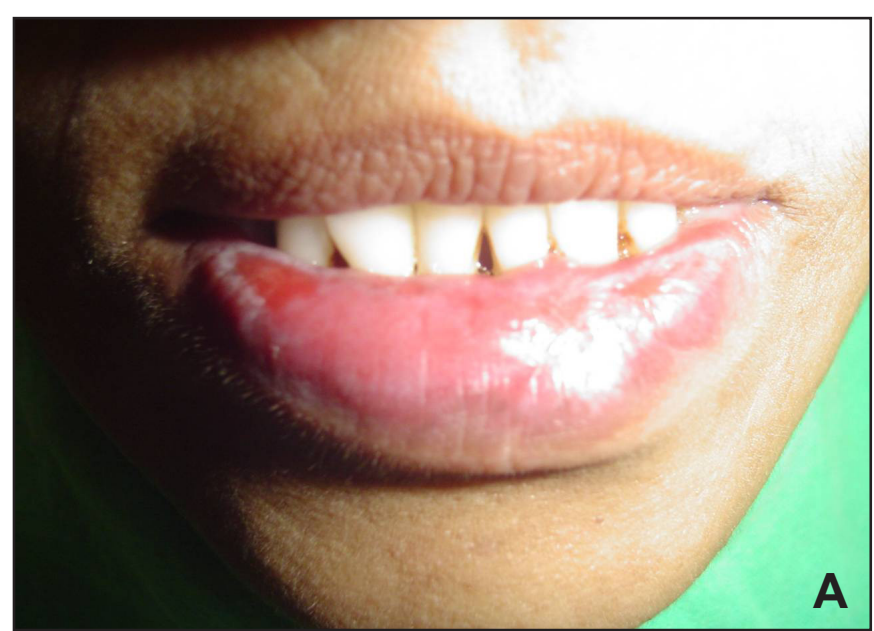

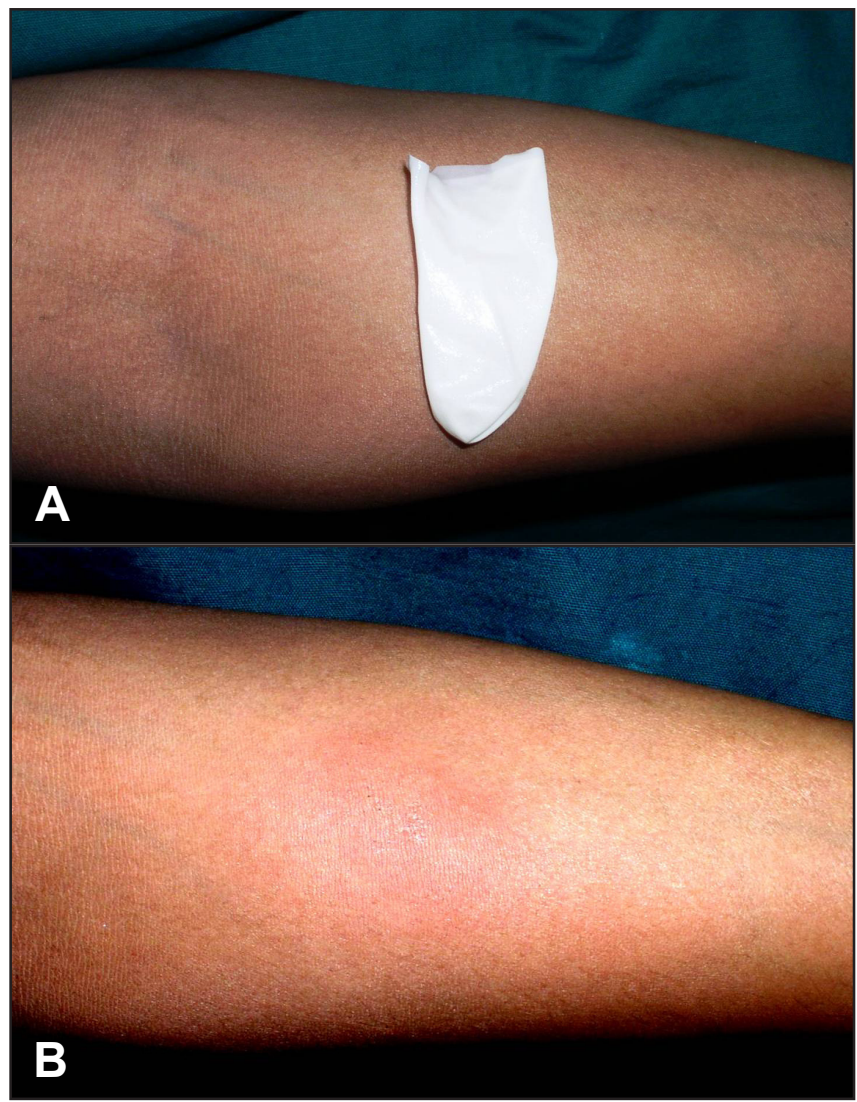

Figure 2. $A=$ The allergen test performed using cut glove finger tip on the patient's forearm.

$\mathrm{B}=$ Erythematous areas noticed at the site of application.

\section{DISCUSSION}

Latex, used as the raw material for natural rubber, sometime induces immediate and delayed hypersensitivity reactions $[1,3]$. There has been a rise in the latex induced allergic reaction in the recent years in a dental team as well as in the patients possibly due to the increased use of latex gloves and rubber dam [21]. Rare cases of the allergic stomatitis secondary to

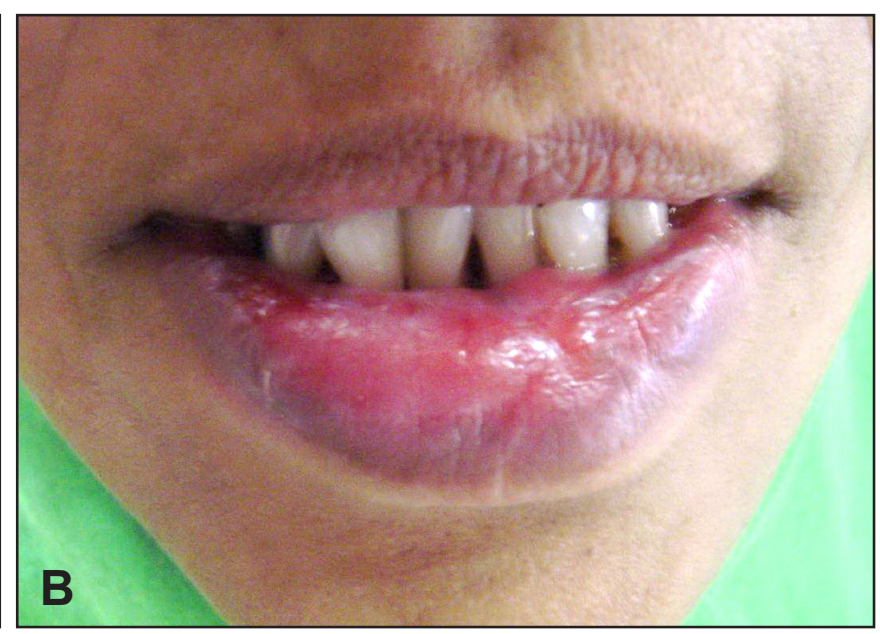

Figure 3. $A=$ Healing of the lesion at the time of discharge. $B=$ Complete healing of the lesion after 8 months. 
orthodontic rubber bands have also been reported [22]. Patient, presented here was subjected to the repeated latex gloves contact during the impression procedures. There are 3 types of reactions to the latex products: irritant contact dermatitis, allergic contact dermatitis, and immediate allergic reactions [4,5]. Our patient exhibited allergic contact cheilitis. Recently, the cases of immediate, systemic allergic reaction due to rubber dam have been reported [21]. Allergic contact dermatitis is a delayed type IV hypersensitivity mediated by $\mathrm{T}$ cells. Lesions generally appear 48 - 96 hours after exposure; similarly time duration was reported by our patient. Clinical manifestations include pruritis, scales, crusts, scabs, papules and vesicles $[\underline{23}, 24]$. Our patient also reported with lip ulcerations two days after the latex contact. Oral mucosal involvement is relatively rare due to 2 reasons: primarily saliva washes off the sensitizers thus not allowing adequate contact time, secondarily abundant vasculature aids in rapid clearing of the allergens [6]. This could possibly explain the lack of oral mucosal lesions in presented patient. No single diagnostic test is $100 \%$ accurate and there is still no "gold standard" for diagnosing allergy to the latex. The most common tests used are patch test, use test and the skin prick test. They are relatively quick, inexpensive but they also carry higher risks for potentially serious systemic reactions during the testing [25-27].

The use test is performed with a fingertip cut from a latex glove and moistened with saline solution. The latex is applied to the skin of a patient for 15 minutes. Urticarial pruritis or erythema shows a positive result. If no reaction occurs, an entire saline-soaked surgical glove can be applied to patient's hand until a reaction occurs or for a maximum of 15 minutes [1]. The same test was used in our case because prevention is better than cure. Use of the latex-free gloves and equipments in high-risk patients are suggested. Cotton liners and barriers may also be effective. Polythene gloves during the treatment and scaling procedures were used in the present case. Some authors suggest administering prophylactic antihistamines, such as diphenhydramine, or corticosteroids, such as prednisone, before the dental treatment to those at known risk [28].

Contact dermatitis and type IV allergy may be managed with topical corticosteroids and antihistaminics as it was in reported case $[\underline{1}, \underline{29}]$. The American Society of Anesthesiologists Task Force of Latex Sensitivity recommends that patients who are latex allergic have a surgical procedure performed as the first case in the morning, when the levels of latex aeroallergens are the least [30]. A strategy was developed for the management of latex allergic patients that consists of a collection of information on medical equipment including latex-free and latex-containing items and latex-containing items that could be used with modification [31]. Minimizing latex exposure is the most effective strategy when treating latex sensitive patients. Latex alternatives (vinyl, nitrile or silicone) and powder-free gloves should be used in the dental clinic to prevent the sensitization of patients and personnel [30-33].

\section{CONCLUSIONS}

Although old age and diabetes do not have any proven link to allergic reaction, special care is required to prevent secondary wound infection due to immunocompromised state. Case reports pertaining to allergic chelitis secondary to the latex in elderly diabetics are sparse, making the presented case unique. Application of a relatively simple use test for detection of suspected latex allergen and comprehensive management of an immunocompromised allergic patient are also highlighted in the present case.

\section{ACKNOWLEDGMENTS AND DISCLOSURE STATEMENTS}

The authors declare that they have no conflict of interests.

\section{REFERENCES}

1. Spina AM, Levine HJ. Latex allergy: a review for the dental professional. Oral Surg Oral Med Oral Pathol Oral Radiol Endod. 1999 Jan;87(1):5-11. Review. [Medline: 9927072] [doi: 10.1016/S1079-2104(99)70286-6]

2. Thurlow KL. Caring for patients with latex allergies. Home Healthc Nurse. 1999 Oct;17(10):625-9. Review. [Medline: 10818836] [doi: 10.1097/00004045-199910000-00003]

3. Kean T, McNally M. Latex hypersensitivity: a closer look at considerations for dentistry. J Can Dent Assoc. 2009 May;75(4):279-82. Review. [Medline: 19422750] [FREE Full Text]

4. Roy A, Epstein J, Onno E. Latex allergies in dentistry: recognition and recommendations. J Can Dent Assoc. 1997 Apr;63(4):297-300. Review. [Medline: 9125845 ]

5. Amin A, Palenik CJ, Cheung SW, Burke FJ. Latex exposure and allergy: a survey of general dental practitioners and dental students. Int Dent J. 1998 Apr;48(2):77-83 [Medline: 9779087] 
6. Blanco C. Latex-fruit syndrome. Curr Allergy Asthma Rep. 2003 Jan;3(1):47-53. Review. [Medline: 12542994] [doi: 10.1007/s11882-003-0012-y]

7. Tran A, Pratt M, DeKoven J. Acute allergic contact dermatitis of the lips from peppermint oil in a lip balm. Dermatitis. 2010 Apr;21(2):111-5. [Medline: 20233551]

8. Chin SM, Ferguson JW, Bajurnows T. Latex allergy in dentistry. Review and report of case presenting as a serious reaction to latex dental dam. Aust Dent J. 2004 Sep;49(3):146-8. [Medline: 15497359] [doi: 10.1111/j.1834-7819.2004.tb00064.x]

9. Strauss RM, Orton DI. Allergic contact cheilitis in the United Kingdom: a retrospective study. Am J Contact Dermat. 2003 Jun;14(2):75-7. [Medline: 14749024]

10. Castanedo-Tardan MP, Zug KA. Patterns of cosmetic contact allergy. Dermatol Clin. 2009 Jul;27(3):265-80, vi. Review. [Medline: 19580921] [doi: 10.1016/j.det.2009.05.014]

11. Beukers SM, Rustemeyer T, Bruynzeel DP. Cheilitis due to olive oil. Contact Dermatitis. 2008 Oct;59(4):253-5. Review. [Medline: 18844707] [doi: 10.1111/j.1600-0536.2008.01421.x]

12. Chiu CS, Tsai YL. Cheilitis granulomatosa associated with allergic contact dermatitis to betel quid. Contact Dermatitis. 2008 Apr;58(4):246-7. [Medline: 18353040] [doi: 10.1111/j.1600-0536.2007.01269.x]

13. Jacob SE, Chimento S, Castanedo-Tardan MP. Allergic contact dermatitis to propolis and carnauba wax from lip balm and chewable vitamins in a child. Contact Dermatitis. 2008 Apr;58(4):242-3. [Medline: 18353036] [doi: 10.1111/j.1600-0536.2007.1261.x]

14. Pastor N, Silvestre JF, Mataix J, Lucas A, Pérez M. Contact cheilitis from bisabolol and polyvinylpyrrolidone/ hexadecene copolymer in lipstick. Contact Dermatitis. 2008 Mar;58(3):178-9. [Medline: 18279165] [doi: 10.1111/j.1600-0536.2007.01225.x]

15. Schram SE, Glesne LA, Warshaw EM. Allergic contact cheilitis from benzophenone-3 in lip balm and fragrance/ flavorings. Dermatitis. 2007 Dec;18(4):221-4. [Medline: 18021603] [doi: 10.2310/6620.2007.06071]

16. Lavy Y, Slodownik D, Trattner A, Ingber A. Toothpaste allergy as a cause of cheilitis in Israeli patients. Dermatitis. 2009 Mar-Apr;20(2):95-8. [Medline: 19426615]

17. Farina R, Andreotti C. Chronic relapsing allergic contact cheilitis from a toothpaste. A case report. Minerva Stomatol. 2007 Mar;56(3):145-52. [Medline: 17327819]

18. Kosti E, Lambrianidis T. Endodontic treatment in cases of allergic reaction to rubber dam. J Endod. 2002 Nov;28(11):787-9. [Medline: 12470026] [doi: 10.1097/00004770-200211000-00010]

19. Sunay H, Tanalp J, Güler N, Bayirli G. Delayed type allergic reaction following the use of nonlatex rubber dam during endodontic treatment. Int Endod J. 2006 Jul;39(7):576-80. [Medline: 16776762] [doi: 10.1111/j.1365-2591.2006.01127.x]

20. Torgerson RR, Davis MD, Bruce AJ, Farmer SA, Rogers RS 3rd. Contact allergy in oral disease. J Am Acad Dermatol. 2007 Aug;57(2):315-21. Epub 2007 May 25. [Medline: 17532095] [doi: 10.1016/j.jaad.2007.04.017]

21. de Andrade ED, Ranali J, Volpato MC, de Oliveira MM. Allergic reaction after rubber dam placement. J Endod. 2000 Mar;26(3):182-3. [Medline: 11199717] [doi: 10.1097/00004770-200003000-00014]

22. Cohen DM, Hoffman M. Contact stomatitis to rubber products. Oral Surg Oral Med Oral Pathol. 1981 Nov;52(5):491-4. [Medline: 6946377] [doi: 10.1016/0030-4220(81)90360-1]

23. Nettis E, Colanardi MC, Ferrannini A, Tursi A. Reported latex allergy in dental patients. Oral Surg Oral Med Oral Pathol Oral Radiol Endod. 2002 Feb;93(2):144-8. [Medline: 11862201] [doi: 10.1067/moe.2002.120805]

24. Tikku AP, Sonia J. Emergence of a new threat: Latex allergy - A case report. Endodontology 2001 Jun; 13(1): 24-26. [URL: http://medind.nic.in/eaa/t01/i1/eaat01i1p24g.pdf]

25. Johansen JD, Rastogi SC, Menné T. Contact allergy to popular perfumes; assessed by patch test, use test and chemical analysis. Br J Dermatol. 1996 Sep;135(3):419-22. [Medline: $\underline{\text { 8949436] [doi: 10.1111/j.1365-2133.1996.tb01506.x] }}$

26. Zug KA, Kornik R, Belsito DV, DeLeo VA, Fowler JF Jr, Maibach HI, Marks JG Jr, Mathias CG, Pratt MD, Rietschel RL, Sasseville D, Storrs FJ, Taylor JS, Warshaw EM; North American Contact Dermatitis Group. Patch-testing North American lip dermatitis patients: data from the North American Contact Dermatitis Group, 2001 to 2004. Dermatitis. 2008 Jul-Aug;19(4):202-8. [Medline: 18674455]

27. Khamaysi Z, Bergman R, Weltfriend S. Positive patch test reactions to allergens of the dental series and the relation to the clinical presentations. Contact Dermatitis. 2006 Oct;55(4):216-8. [Medline: 16958919] [doi: 10.1111/j.1600-0536.2006.00905.x]

28. Nainar SM. Dental management of children with latex allergy. Int J Paediatr Dent. 2001 Sep;11(5):322-6. Review. [Medline: 11572261] [doi: 10.1046/j.0960-7439.2001.00287.x]

29. MacCracken J, Stenger P, Jackson T. Latex allergy in diabetic patients: a call for latex-free insulin tops. Diabetes Care. 1996 Feb;19(2):184. [Medline: 8718449 ]

30. Hepner DL, Castells MC. Latex allergy: an update. Anesth Analg. 2003 Apr;96(4):1219-29. Review. [Medline: 12651689] [doi: 10.1213/01.ANE.0000050768.04953.16] [FREE Full Text]

31. Dakin MJ, Yentis SM. Latex allergy: a strategy for management. Anaesthesia. 1998 Aug;53(8):774-81. [Medline: 9797522] [doi: 10.1046/j.1365-2044.1998.00531.x]

32. Trudgen K. Latex Allergy: Implications for Health Care Workers and Health Care Consumers. [URL: http://www.defence.gov.au/health/adf_nurses/Archive/Latex_Allergy.pdf] 
33. Gawkrodger DJ. Investigation of reactions to dental materials. Br J Dermatol. 2005 Sep;153(3):479-85. Review. [Medline: 16120131] [doi: 10.1111/j.1365-2133.2005.06821.x]

\section{To cite this article:}

Shetty SR, Rangare A, Babu S, Rao P. Contact Allergic Cheilitis Secondary to Latex Gloves: a Case Report.

J Oral Maxillofac Res 2011;2(1):e5

URL: http://www.ejomr.org/JOMR/archives/2011/1/e5/v2n1e5ht.pdf

doi: $10.5037 /$ jomr.2011.2105

Copyright (C) Shetty SR, Rangare A, Babu S, Rao P. Accepted for publication in the JOURNAL OF ORAL \& MAXILLOFACIAL RESEARCH (http://www.ejomr.org), 23 January 2011.

This is an open-access article, first published in the JOURNAL OF ORAL \& MAXILLOFACIAL RESEARCH, distributed under the terms of the Creative Commons Attribution-Noncommercial-No Derivative Works 3.0 Unported License, which permits unrestricted non-commercial use, distribution, and reproduction in any medium, provided the original work and is properly cited. The copyright, license information and link to the original publication on (http://www.ejomr.org) must be included. 